\title{
O UOBECNIENIU DUSZY, SOKRATESIE PSYCHAGOGU I SZTUCE UŚWIADOMIONEGO MÓWIENIA
}

\begin{abstract}
Streszczenie. W artykule podjęta jest próba intuicyjnej syntetycznej interpretacji sokratejskiej maieutyki w duchu psychologii homeryckiej. Bazując na tej interpretacji, opracowano ćwiczenie uświadomionego mówienia, które zostało włączone do zajęć akademickich: Jak praktycznie wykorzystać własna głupotę? - doradztwo filozoficzne w warsztacie psychologa, prowadzonych na Uniwersytecie Warszawskim i w Szkole Wyższej Psychologii Społecznej w latach 2004-2012. Na gruncie akademickim były to pierwsze w Polsce seminaria poświęcone doradztwu filozoficznemu. Podczas ćwiczeń studenci byli proszeni o zapisywanie swoich obserwacji. Niektóre ćwiczenia były filmowane. W ten sposób został zebrany bardzo ciekawy materiał, który może być podstawą do dalszych poszukiwań teoretycznych i empirycznych. W artykule krótko przedstawiam, czym jest uświadomione mówienie, prezentuję zapiski z ćwiczeń studentów oraz wskazuję na krótki materiał filmowy.

Słowa kluczowe: psychologia homerycka, dusze nie-cielesne (thymos i nous), dusze cielesne (dusza-serce - kradié; dusza-przepona - fren), metoda maieutyczna, sztuka uświadomionego mówienia, uobecnienie siebie, ćwiczenia duchowe
\end{abstract}

1. Wprowadzenie. 2. Psychologia homerycka: 2.1. Dusze cielesne: kradié i fren; 2.2. Dusze nie-cielesne: thymos i nous, 3. Relacja między sercem i umysłem. 4. Uświadomione mówienie jako uobecnienie siebie. 5. Ćwiczenia duchowe - relacje osób ćwiczących. 6. Zarys dalszych badań. 7. Zakończenie.

\section{WPROWADZENIE}

W artykule przedstawiam nowe spojrzenie na sokratejską maieutykę i spostrzeżenia z jej zastosowania podczas warsztatów Jakpraktycznie wykorzystać wtasna gtupote - doradztwo filozoficzne w warsztacie psychologa, prowadzonych w latach 2004-2012 na Wydziale Psychologii Uniwersytetu Warszawskiego oraz w Szkole Wyższej Psychologii Społecznej w Warszawie. Były to pierwsze w Polsce seminaria 
z doradztwa filozoficznego prowadzone w ramach kursów akademickich. Ich zapowiedzią było pilotażowe seminarium Wychowawcze i rozwojowe aspekty fllozofii $\mathrm{z}$ roku 2002.

Niektóre $\mathrm{z}$ wątków podjętych w tekście, omówione zostały podczas konferencji Wokót idei doradztwa filozoficznego, zorganizowanej w Opolu w dniach 26-28.11.2015 r. przez Instytut Filozofii Uniwersytetu Opolskiego, Stowarzyszenie Doradztwa Filozoficznego „Pogadalnia” i Studenckie Koło Filozoficzne Uniwersytetu Opolskiego.

Poniższa, intuicyjna interpretacja syntetyczna metody majeutycznej stawia sobie za cel odtworzenie antycznych ćwiczeń duchowych lub opracowanie ćwiczeń nowych opartych na podstawach starożytnych. Inspiracją do poszukiwań na tym polu były prace: Adama Krokiewicza $^{1}$, Pierre Hadota ${ }^{2}$, Juliusza Domańskiego ${ }^{3}$ oraz Tadeusza Zielińskiego ${ }^{4}$. Niektóre wnioski i obserwacje poczynione w artykule nawiązują do zarysowanej, ale nigdy nie rozwiniętej przez A. Krokiewicza, teorii nadświadomości 5 .

Równolegle zainteresowania moje ciążą w kierunku ustalenia zakresu doradztwa filozoficznego i terapii filozoficznej oraz wyznaczenia odpowiadających im metod. Jedną $\mathrm{z}$ nich jest $\mathrm{w}$ moim przekonaniu uświadomione mówienie, którego walory terapeutyczne chciałbym zweryfikować w szerszym projekcie badawczym ${ }^{6}$.

1 A. Krokiewicz, Zarys filozofii greckiej, Warszawa 2000, 15-525; tenże, Sokrates. Etyka Demokryta i hedonizm Arystypa, Warszawa 2000, 7-145.

2 P. Hadot, Filozofia jako ćwiczenie duchowe, tłum z fr. P. Domański, Warszawa 2003, 5-351; tenże, Czym jest filozofia starożytna, tłum z fr. P. Domański, Warszawa 2003, 20-378.

3 J. Domański, Metamorfozy pojęcia filozofii, Warszawa 1996, 1-97.

4 T. Zieliński, Psychologia homerycka, tłum. z ros. T. Kobierzycki, Heksis (1922/1999)1-2, 3-33.

5 D. Dembińska-Siury, Adama Krokiewicza teoria nadświadomości, Przegląd Humanistyczny (1987)31, 21-34.

6 Dzieląc się obserwacjami, chciałbym zachęcić innych do zintegrowania wysiłków do dalszych poszukiwań i badań zmierzających w kierunku opracowania nowych narzędzi doradztwa filozoficznego lub terapii filozoficznej. Jeżeli wspólnym wysiłkiem uda się wypracować i uzasadnić powstałe metody, to współczesne doradztwo filozoficzne zwłaszcza to polskie - ugruntuje swoją pozycję i jeszcze prężniej zacznie działać. 
Poszukując argumentów dla nowego spojrzenia na sokratejską maieutykę, przyjąłem, że poematy Homera nie są wyłącznie poetycką metaforą, tylko wiernym zapisem wiedzy psychologicznej, oddającej doświadczenie wewnętrzne człowieka antycznego. Niegdyś takie podejście obrał archeolog Heinrich Schliemann. Potraktował on krajobrazy opisywane przez Homera nie jako fikcję literacką, lecz jako wskazówki do odnalezienia miasta obleganego w starożytności przez Achajów. Takie nastawienie zaowocowało odkryciem Troi. Naiwne w założeniach wstępnych i niekiedy dosłowne czytanie Homera pozwoliło mi zżyć się z jego poematami, odkryć wcześniej niezauważane pokłady rozumienia, które stały się podwaliną pod nową interpretację sokratejskiej maieutyki i opracowanie ćwiczenia uświadomionego mówienia.

Opisy przeżyć duchowych bohaterów Iliady i Odysei, pozostawione przez Homera, stały się dla mnie wskazówkami do odtworzenia podobnych przeżyć u osób współcześnie praktykujących ćwiczenia duchowe. Kolejnym krokiem było zinterpretowanie metody majeutycznej Sokratesa, rozumianej jako uświadomione mówienie, w duchu psychologii homeryckiej. Mimo że psychologia homerycka nie przystaje do psychologii, którą znamy z czasów sokratejskich, niemniej założyłem, że zmiany, które zaszły w ciągu kilku stuleci dotyczyły doprecyzowania siatki pojęciowej i „rozlokowania” części duchowych w ciele człowieka, natomiast istota działania zjawisk duchowych (tj. sposób oddziaływania duszy na ciało, a co za tym idzie sposób ich percypowania) pozostał niezmieniony? ${ }^{7}$. Efekty opracowanych tą droga ćwiczeń wykroczyły daleko poza moje oczekiwania i przypuszczenia.

7 Warto zauważyć, że filozofowie antyczni wykazywali się wysoką znajomością dzieł Homera i chętnie się do nich odwoływali. Demokryt rozwija idee Homera w nauce o sercu posłusznym umysłowi. Naukę Homera rozwija również Pirron, który korzysta ze „,schematu dwóch dusz" a także wprowadza jako ćwiczenie rozmowę z sobą samym (u Homera jest to przemawianie do własnego serca). Wątek dwoistego charakteru ludzkiej jaźni obecny jest u Platona, Arystotelesa, Plotyna, stoików (A. Krokiewicz, Zarys filozofii greckiej, dz. cyt., 377). 


\section{PSYCHOLOGIA HOMERYCKA}

Przyjmując poematy Homera za źródło wiedzy o antycznej umysłowości, przypomnijmy główne założenia psychologii homeryckiej. Według lingwistyczno-psychologicznych badań Tadeusza Zielińskiego na obraz „duchowej anatomii” człowieka składają się w Ilia$d z i e$ i Odysei dwa rodzaje dusz: cielesne i nie-cielesne. Przejawem pierwszych są zarządzające organami psychofizycznymi: dusza-serce (kradié, ker, etor, prapides) i dusza-przeponowa (fren); drugich - będące $\mathrm{w}$ dwóch postaciach dusze: thymos i nous, kierujące organami psychicznymi. Miejscem pobytu dusz nie-cielesnych jest pierś (sthetos), w której są one „zamknięte” pełniąc funkcję emocjonalną i intelektualną . Podziału na cielesny i nie-cielesny aspekt duszy używał Homer do opisu funkcjonowania człowieka. Istota ludzka żyje, póki psyche trzyma ją przy życiu. Nie bierze ona czynnego udziału w życiu człowieka i nie odpowiada za jego intelektualną oraz afektywną stronę. Zasadniczym polem działania psyche są losy człowieka po śmierci. Taki stan dobrze oddają słowa Pindara:

„Ciało każdego podlega wszechwładnej śmierci,

Jednak jeszcze pozostaje odbicie życia.

To tylko pochodzi od bogów.

Śpi, kiedy członki się trudzą,

Lecz śpiącym często w snach pokazuje

Nadchodzący wyrok w sprawach trudnych i przykrych"9.

Za postawę człowieka (intelektualną, emocjonalną i etyczną) odpowiada zasadniczo serce i umysł, ich wzajemna relacja oraz zdolność do współpracy. Zapoznanie się z opisaną przez Homera "mechaniką” tego współdziałania oraz fenomenem utracenia i odzyskania przez człowieka jego dusz nie-cielesnych, pomoże nam zrozumieć, czym było uobecnienie siebie w czasach antycznych i na czym polegało

8 T. Zieliński, dz. cyt. 5-6.

9 M. Stuligrosz, Gnoza w twórczości Pindara, Poznań 2002, 96. 
ćwiczenie uobecniania siebie, tj. przywoływania własnego nous i thymos.

\subsection{Dusze cielesne: kradié i fren}

Fizyczna dusza-serce (kradié) ma charakter emocjonalno-uczuciowy. Jej somatyczna funkcja przejawia się „biciem w piersiach”. Tu zamieszkuje miłość, radość, męstwo, gorycz, strach, gniew i niemoc. Serce raduje się, cieszy, zachwyca i śmieje się. Sercem spełnia się męstwo, stąd też płynie miłość rodzica do dziecka. Gdy sercem owładnie silne strapienie (akhos), serce „skarży się, wyraża skruchę, mięknie”. Ten stan dobrze oddaje sformułowanie „będziesz pożerać własne serce"10.

Strach doprowadza do trzęsienia się kolan i kołatania serca jako oznaki słabości.

„Rzekł, a pod nią nogi

Zatrzęsły się, drży serce (etor), usta ściął ból srogi"11.

Stronę fizyczną posiada również dusza-przepona (fren, frenes). Jest ona cielesnym aspektem duszy-rozumowej (nous). Ona odczuwa miłość jako „pokrywającą ją” troskę i jest organem radości. Tu przebywa "gorycz” („targa ona błoną”, tj. diafragmą, „uderza ją" i „kąsa przez nią" człowieka) a także otchłań smutku, strachu i gniewu. Działanie na błonę przeponową może powodować otępienie świadomości. Tak dzieje się, gdy niepamięć ściera $\mathrm{z}$ błony przeponowej przedstawienia, zalewana jest przez sen, obciąża ją wino lub uderza w nią Boża odpłata $(a t a)^{12}$. Mimo iż zdarzają się u Homera akapity zacierające

10 T. Zieliński, dz. cyt. 9. Warto przypomnieć, że jedna z maksym Pitagorasa nakazywała, by: „własnego serca nie zjadać”, co znaczyło: „nie należy się gryźć zmartwieniami i smutkami”. D. Leartios, Żywoty i poglądy słynnych filozofów, tłum. z gr. K. Leśniak, I. Krońska, W. Olszewski, Warszawa 1988, 479.

11 Homer, Odyseja, tłum z gr. L. Siemieński, Kraków 2003, IV.700-705, 58.

12 T. Zieliński, dz. cyt. 12. 
różnice pomiędzy duszą-serce i duszą-przeponową, to jednak tę drugą uznaje on za narząd intelektu i świadomości.

W przypadku serca cielesne funkcje duszy mają wyłącznie emocjonalny, a w przypadku przepony - w większości intelektualny charakter. Dodatkowo serce jest traktowane jako czynny narząd życia psychicznego, przepona - jako narząd bierny. Pierwsze przeżywa: płacze, skarży się, martwi, oczekuje, troszczy, niepokoi. Druga doznaje - przyjmuje oddziaływanie afektów, ale ich nie zabarwia emocjonalnie ${ }^{13}$ Będąc w obszarze serca, bohater antyczny odbiera uczucia oraz emocje i niejako im się poddaje, co ma przełożenie na jego stan emocjonalny. $Z$ kolei w obszarze przeponowym (intelektualnym), postrzega np. cierpienie lub gniew, ale stan emocjonalny nim nie owłada. W dużym uproszczeniu możemy powiedzieć, że serce w swym funkcjonowaniu jest zasadniczo steniczne, przepona - asteniczna.

\subsection{Dusze nie-cielesne: thymos i nous}

Niecielesne funkcje duszy-serca (thymos) ukazuje Homer jako zasadę życia. Kto w walce po uderzeniu ożywa, u tego thymos zbiera się w piersi lub przeponie ${ }^{14}$. Funkcja thymos zbliżona jest tu do psyche. Thymos można odbudowywać, czerpiąc wrażenia m.in. z obcowania z innymi, biesiadowania, jedzenia, picia, podziwu czy zachwytu dla kogoś lub czegoś. Wysiłek lub rana osłabiają thymos. „Thymos raduje się lub my się radujemy w swoim thymos, co nas cieszy, to jest miłe dla naszego thymos; także łzami można nasycić się w swoim thymos"15. Wraz z duchowym zadowoleniem bardzo często współwystępują uczucia miłości, przyjaźni, męstwa. Co dla nas ciekawe, również

13 Tamże, 14-15.

14 Takie podejście żywo przypomina obserwacje antycznych Egipcjan. „Moja dusza omdlała, moje ciało ugięło się, a serce uciekło z piersi: nie wiedziałem już, co życie, co śmierć. Bóg skłonił mnie do tej ucieczki". S. Morenz, Bóg i człowiek w starożytnym Egipcie, tłum. z niem. M. Szczudłowski, Warszawa 1972, 74.

15 T. Zieliński, dz. cyt. 17. 
jako jedną $\mathrm{z}$ form myślenia ${ }^{16}$ przedstawia się rozmowę $\mathrm{z}$ thymos ${ }^{17}$. Odyseusz przygotowując się do ostatecznego rozrachunku z gachami rozważa w sercu-duszy (thymos) zaistniałe okoliczności. Na widok służących udających się na schadzkę z gachami, jego cielesne serce (ker, etor) wpada we wzburzenie. Odyseusz uspokaja je, dając mu bodziec cielesny i upomnienie słowne. Cała sytuacja wygląda tak, jakby rozważna i zdystansowana przemowa do samego siebie (obszar duszy-przeponowej - nous) poskromiła cielesne-serce $(k e r)^{18}$. Wzmiankę o myśleniu jako rozmowie z samym sobą znajdujemy też na przykład u Platona, we fragmencie rozmowy Sokratesa z Teajtetem ${ }^{19}$.

16 Tamże, 19.

17 „Tak mówił, Nestoryda radził się swojego serca (thymos), czy wypada spełnić prośbę”. Homer, Odyseja, tłum. z gr. J. Parandowski, Warszawa 1964, 229; „Rzekł, a Nestoryd w duchu (thymos) już wszystko obliczył, / Aby spełnić najlepiej, co sobie druh życzył, / I ta rada najlepszą zdała się w tej mierze". Homer, Odyseja, tłum z gr. L. Siemieński, dz. cyt., XV.197-199, 188.

18 „Bijąc się w piersi (sthetos) karcił swe serce (kradie): Znieś i to, moje serce, jużeś i bardziej psie dni znosiło, jak ów, kiedy nieokiełznany Kiklop pożerał dzielnych towarzyszy. Twoja to wówczas roztropna odwaga wyprowadziła mnie z pieczary, w której sądziłem, że zginę. Tak przemawiał do serca (kradie) miłego, a wierne, cierpliwe serce (etor) było mu posłuszne". J. Parandowski, dz. cyt., 296.

„Ale bijąc się w piersi (sthetos), poryw ten uśmierzył:

»Cierp, serce (kradie)! Przecież nieraz gorsześ przecierpiało,

Jak z Cyklopem, gdy szarpał żywcem druhów ciało!

A jednak to się zniosło wyszedłem z tej matni,

Pewien, że przyszedł na mnie w życiu dzień ostatni«.

Tak mówił (muthoi - mowa, słowo wypowiedziane ustami) i ukajał w głębi burze duszne (etor).

Serce (kradie) się ukoiło, rozkazom posłuszne".

Homer, Odyseja, tłum z gr. L. Siemieński, dz. cyt., XX.15-25, 247.

19 „Sokrates: Bardzo pięknie. A myśleniem (dianoia) nazywasz to samo, co i ja?

Teajtet: A ty co tak nazywasz?

Sokrates: Rozmowę (logon), którą dusza (psyche) sama z sobą prowadzi, cokolwiek weźmie pod uwagę. Objawiam ci to, chociaż sam dobrze nie wiem. Tylko tak mi się przedstawia dusza, kiedy rozmyśla, że niby rozmawia - sama sobie zadaje pytania i odpowiedzi daje, i mówi »tak«, i mówi »nie«. A kiedy granice pewne pociągnie - dusza czasem wolniej, czasem szybciej miarkuje - kiedy w końcu jedno i to samo powie (phemi), i już się nie waha, na obie strony, uważamy to za jej sąd. Zatem ja sądzeniem nazywam mówienie 
Wiemy z grubsza, jak Homer używał pojęcia thymos. Przyjrzyjmy się teraz, jak w poematach Homera używany jest termin nous (,świadomość”). Najczęściej przeciwstawiany jest on nieświadomemu lub półświadomemu stanowi człowieka. Tak rozumiana świadomość odróżnia martwego od żywego. Jest jeszcze drugie znaczenie, według którego nous jest „,magazynem” umysłu, „iloczynem” zdolności umysłowych, doświadczenia oraz wiedzy człowieka i możliwości ich wykorzystywania, „dzięki którym jeden odróżnia się od drugiego”20. Nous Odysa zapewnia jego ludziom ujście z rąk Cyklopa, ranny wódz swoim nous pomaga wojownikom rozkazując, woźnica pobudza nim konie.

Podział na dusze cielesne i nie-cielesne uwidacznia się, gdy w poematach mowa jest o śmierci człowieka. Homer nie używa, takich określeń, jak: „stracił frenes” lub „odjęli mu frenes” np. w wyniku walki podczas bitwy. Wprowadza je natomiast, gdy mówi o thymos: „stracił thymos”, „zostawił go thymos”, „uleciał jego thymos”, „zgubił thymos". Thymos zachowuje analogię do duszy - psyche. I podobnie jak ona, w chwili śmierci, porzuca ciało człowieka ${ }^{21}$. Z tą różnicą, że thymos bierze czynny udział w życiu człowieka, zaś psyche - nie. Jej rola i działanie objawia się dopiero po śmierci człowieka.

Dla naszych dalszych rozważań niezmiernie ważne jest podkreślenie, że działający człowiek może utracić swój thymos i powtórnie go odzyskać. Odzyskanie duszy nie-cielesnej, jej pow tórne osadzenie w ciele człowieka, będziemy dalej nazywać „uobecnieniem”.

(logon), a sądem nazywam myśl (logos) tylko nie do kogoś innego, ani głosem (phone), tylko po cichu (sigao), do siebie samego. A ty jak?

Teajtet: I ja tak samo" (...)

Sokrates: Przypomnijże sobie, czyś kiedykolwiek mówił (eipon) do siebie (seauton), że to, co piękne, jest właściwie brzydkie, albo to, co niesprawiedliwe, że jest sprawiedliwe (...)", Platon, Teajtet, w: Dialogi, tłum z gr. W. Witwicki, Kęty 1999, 2, 399-400 (189 E-190 C).

20 T. Zieliński, dz. cyt., 21.

21 T. Kobierzycki, Miejsce i rola uczuć w opisie duszy cielesnej i niecielesnej u Homera, Heksis (2010)4, 12. 
Tak dzieje się z Andromachą, która widząc, jak Achilles poniewiera ciało jej męża, doznaje emocjonalnego szoku, traci przytomność i upada na wznak. Przypuszczać możemy, że owładnięta głębokim żalem i cierpieniem sama zapewne nie chce żyć. Poeta ujmuje ten dramatyczny moment, zapisując, że „ledwie psyche z niej nie uciekła”. Skoro jednak nie doszło do całkowitego odejścia psyche, która w sposób ostateczny decyduje o życiu lub śmierci człowieka, to po chwili Andromacha odzyskuje oddech, thymos zbiera się w jej przeponie (frenes) i wtedy głośno przemawia ${ }^{22}$. Thymos ulatuje również w chwili omdlenia: Odys, dopływający do brzegu Feaków, „leżał bez tchu i bez mowy, ledwo żywy, straszne zmęczenie nim owładnęło; lecz gdy wrócił do siebie dech i thymos zebrał się w jego przeponie (frenes)..." 23 i oży ${ }^{24}$.

W przytoczonych fragmentach wyeksponowano sytuacje dramatyczne, w których dochodzi do oddzielenia duszy od ciała. Można zadać pytanie, jak wyglądają relacje dusze-ciało w sytuacjach

22 „Zaraz jej czarnym cieniem oczy noc powlekła, Padła, z omdlałej ledwie dusza (psyche) nie uciekła. (...)

Gdy zmysły (thymos) odzyskała, płacze rozkwilona.

Nad mężem nieszczęśliwym nieszczęśliwa żona".

Homer, Iliada, tłum z gr. L. Siemieński, Kraków 2004, XXI.455-465, 247.

23 „Ugięły się pod Odyssem kolana, krzepkie ramiona opadły, albowiem morze złamało w nim serce (ker). Skóra na ciele obrzmiała, woda strumieniem wylewała się z ust i nosa. Bez tchu, bez głosu leżał omdlały pod brzemieniem straszliwego znużenia. Lecz kiedy wrócił mu oddech i serce (thymos) się w piersi (frenes) ocknęło, odwiązał bożą namiotę i puścił na rzekę płynącą do morza”. Homer, Odyseja, tłum. z gr. J. Parandowski, dz. cyt. 104. „Ramionami objął drogiego syna, a omdlewającego przycisnął do piersi niezłomny boski Odys. Gdy wrócił mu oddech (do przepony - fren) i serce (thymos) się ocknęło, przemówił". Homer, Odyseja, tłum. z gr. J. Parandowski, dz. cyt., 349.

„Rzucił mu się w objęcia i upadł w zemdleniu,

Na pierś syna, i w jego zawisnął ramieniu.

A po chwili, gdy duch (thymos) w niego wszedł i ocucił,

W uniesieniu radości takie słowo rzucił".

Homer, Odyseja, tłum z gr. L. Siemieński, dz. cyt. XXIV.357-360, 296.

24 T. Kobierzycki, dz. cyt., 13. 
niezagrażających życiu człowieka i niebędących przykładem oddziaływania silnego afektu. Do pytania tego jeszcze wrócimy.

W poematach Homera krzyżują się dwa dychotomiczne porządki, mające stronę fizyczną i stronę psychiczną. Pierwszy, chcenno-uczuciowy ${ }^{25}$ (kradié-thymos), drugi - rozumowy (frén-nous). W ramach tych dwóch głównych aspektów ludzkiej egzystencji, raz na plan pierwszy wysuwają się pierwiastki chcenno-uczuciowe, innym razem rozumowe. Niekiedy górę bierze strona cielesna, a niekiedy duchowa (psychiczna). Ta ostatnia, rozumiana jako pewna całość (thymos i nous) traktowana jest jako psyche.

\section{RELACJA MIĘDZY SERCEM I UMYSŁEM}

Mając wstępne rozeznanie w „duchowej anatomii” antycznych, przejdziemy teraz do określenia relacji zachodzącej między sercem i umysłem. Dla ułatwienia nie będziemy wyróżniali dalej strony cielesnej i nie-cielesnej, czyli nie będziemy zwracać uwagi na to, czy dane zachowanie chcenno-uczuciowe lub rozumowe ma swoje źródło w aspekcie fizycznym czy psychicznym. Pozostaniemy tylko przy podziale na stronę uczuciową i rozumową.

Naprzeciw opanowanego i rozumnego umysłu stawia Homer uczuciowo-emocjonalne porywy serca. W jurysdykcji umysłu pozostaje poznawanie, planowanie, rozumowanie i wytyczanie przebiegu działań. Domeną serca jest uczuciowość, wola i władza nad ciałem. Posłuszne serce wypełnia nakazy umysłu posługując się odpowiednio ciałem. Może ono jednak wymówić posłuszeństwo i przejąć panowanie nad człowiekiem. Prowadzi to często do zgubnych konsekwencji. Intuicję ma zarówno umysł, jak i serce, z tym, że umysł nakierowuje ją na wiedzę i prawdę, a serce - na mniemanie. Również przejawy

25 Terminu tego (oznaczającego: zapał, zryw serca) używam za A. Krokiewiczem. Tenże, Zarys filozofii greckiej, dz. cyt., s. 44; Studia orfickie. Moralność Homera i etyka Hezjoda, Warszawa 2000, 108. 
woli widoczne są po obu stronach z tą różnicą, że moc serca przerasta wielokrotnie siłę umysłu. To $\mathrm{z}$ tego powodu rozum nie może przemóc serca, lecz może perswadować i nakłaniać je do ustępliwości. Jeśli człowiek jest uważny, myśli, czuje, chce i podejmuje działanie w stanie zgody pomiędzy sercem i umysłem, to można powiedzieć, że jego świadomość (frenes) jest „dobra”.

Obraz ludzkiej psychiki przekazany przez Homera oparty jest na wnikliwej obserwacji życia, a pod tym względem wydaje się być aktualny i dziś. Przyjrzymy się teraz praktycznej roli serca i rozumu.

Obok funkcji podtrzymywania życia, jest jeszcze inna, ważna i bardzo nas interesująca funkcja dusz nie-cielesnych, którą można przyrównać do uwagi. O ile serce (kradié) i przepona (frén) były źródłem myśli i afektów, to dusze, thymos i nous, pełniły m.in. funkcję narządów je odbierających. Dzięki duszy-nous i duszy-thymos odbierał człowiek, nie w sposób bierny, lecz aktywny własne akty myślowe oraz przeżycia.

Podobnie i my współcześnie, skupiając własną uwagę na sobie, sprawiamy, że bodźce do nas napływające odbieramy ze spotęgowaną mocą. Nieraz, gdy ktoś mówi, słyszymy dźwięki, ale ich nie rozumiemy. Dopiero gdy „zbierzemy się w sobie”, pojmujemy sens skierowanych do nas słów. Gdy go w nim nie ma, spostrzegamy jedynie biernie doznania własnego ciała. Podobnie rzecz się ma z bólem, którego nie odczuwaliśmy np. w chwili kontuzji, gdy nasza uwaga była skoncentrowana na świecie zewnętrznym.

Zdaje się, że procesy, które współcześnie wiążemy z uwagą i nadajemy im często zewnętrzny, mechaniczny charakter, antyczni pojmowali osobowo i wewnętrznie - duchowo. W psychologii homeryckiej, traktowane jako autonomiczne, dusze nie-cielesne nous i thymos moga uchwycić intelektualną lub emocjonalną stronę funkcjonowania ludzkiego ciała, gdy są uobecnione w ciele. Ciekawe w tym względzie jest zalecenie Platona: „O czym teraz wciąż mówimy, żeby najwięcej duszę (psyche) od ciała (soma) oddzielić i przyzwyczaić ją do tego, żeby się sama w sobie ze wszystkich zakątków ciała umiała skupić 
i zbierać, i mieszkać, (...) w odosobnieniu, w samej sobie; wyzwolona $z$ ciała, niby $z$ kajdan?" 26 .

I dziś, rozmawiając z kimś nieuważnym lub zatopionym w fantazjowaniu, mamy często poczucie jego „nieobecności” i czekamy, kiedy z uwaga zacznie $z$ nami rozmawiać. Niejednokrotnie i sami siebie nawołujemy do „powrotu do siebie”, mając poczucie „nieistnienia” w wykonywanej czynności.

Potoczne nawyki językowe, towarzyszące tym stanom, dobrze korespondują z homerycką psychologią. Niekiedy powiemy do kogoś biernie nas słuchającego: „wróć”, a i sami przyznajemy się, że „nas nie było" podczas wykonywania jakiejś pracy. Wiele wskazuje na to, że w tych „powrotach” antyczni widzieli coś więcej niż tylko procesy uwagowe.

Procesy, o których mowa, współcześnie łączymy z uwagą. Łatwo to sobie uzmysłowić, gdy wspomnimy sytuację, w której mimo chęci przywołania się do uważnego działania nie możemy spowodować, by nasza własna uwaga podążała za naszymi czynami. Można mieć wtedy poczucie, że „coś”, a raczej „ktoś” w nas postępuje niezgodnie z naszymi oczekiwaniami, że nasza dusza, czy jak byśmy dzisiaj powiedzieli: uwaga, „ulatuje mimo chęci jej utrzymania w ciele”, przy czym trudność może dotyczyć naszej działalności intelektualnej, uczuciowej i emocjonalnej oraz doznaniowej. Niekiedy trudność stwarza nam skupienie się nad czynnościami myślowymi, innym razem - nad czynnościami związanymi z doznaniami lub emocjami. Opisywane procesy stoicy wiązali z uwaga (proskhe), która była dla nich zasadniczą postawą duchową przejawiającą się w ciągłej czujności, rozbudzonej samoświadomości oraz obecności i napięciu ducha. Dzięki takiemu nastawieniu wiedzieli oni, czego pragną i co w każdej chwili robią. Dzięki czujności ducha urzeczywistniana była

26 Platon, Fedon, w: Dialogi, tłum z gr. W. Witwicki, Kęty 1999, 1, 642, (67 C-D). 
podstawowa reguła ich życia - rozróżnienie między tym, co zależy i co nie zależy od człowieka ${ }^{27}$.

\section{UŚWIADOMIONE MÓWIENIE JAKO UOBECNIENIE SIEBIE}

Powstaje pytanie, czy filozofia antyczna wytworzyła skuteczne narzędzie umożliwiające poznanie i zjednoczenie dwóch wspomnianych porządków: rozumu przejawiającego się u człowieka w działaniu dusz fren i nous oraz serca uosabiającego dusze ker i thymos. Dążenia do integracji tych dwóch porządków widoczne są m.in. w nauce Demokryta o eutymii, w poglądach Pirrona na ,nastroje” i ,nieodczuwanie", czy wizji jaźni Plotyna ${ }^{28}$. W moim przekonaniu narzędziem scalającym oba wymienione porządki była sztuka uświadomionego mówienia.

Sztuką uświadomionego mówienia według A. Krokiewicza była dialektyka Sokratesa, a jej głównym celem - zdobycie pojęciowej wiedzy ${ }^{29}$. Wdrażając kogoś do jej zdobycia stosował Sokrates trzy stopnie. Pierwszy stanowiła krytyka (elenktyka). Sokrates „badał” świadomość ucznia, wykazywał mu, że nie wie niczego, i go zawstydzał. Drugi - zachęta (protreptyka): Sokrates dodawał otuchy i doradzał uczniowi, co ma robić, by pozbyć się hańbiącej człowieka „niewiedzy”. Trzeci - pomoc w „uświadomionym mówieniu” i w definiowaniu pojęć (maieutyka). Sokrates zadaje pytania i żąda od ucznia wysiłku w jego odpowiedziach i definicjach ${ }^{30}$. Według Krokiewicza Sokrates wymagał w ten sposób od swoich uczniów „uświadomionego

27 P. Hadot, Filozofia jako ćwiczenie duchowe, tłum. z fr. P. Domański, Warszawa 2003, 17.

28 Dla Plotyna „Jaźń jest podwójna, albo z zaliczeniem zwierzęcia, albo już tylko to, co nad nim. Zwierzę to ożywione ciało. Prawdziwy człowiek jest zaś inny: jest wolny od tych nieczystości i posiada cnoty, związane z myślą czystą, które mają siedlisko w oddzielającej się duszy samej, oddzielającej się i oddzielnej, kiedy jeszcze tu przebywa. Bo wtedy zaiste, kiedy zupełnie odejdzie, odchodzi z nią także ta druga wypromieniowana z niej dusza (Enn. I.1.10)". Zob. A. Krokiewicz, Zarys filozofii greckiej, dz. cyt., 377-378.

29 A. Krokiewicz, Sokrates. Etyka Demokryta i hedonizm Arystypa, dz. cyt. 66.

30 Tamże, 67. 
mówienia", tj. zdawania sobie sprawy ze znaczenia używanych wyrazów oraz powiązanych z nimi uczuć i doznań. Był to wymóg ,jasnego myślenia", o którym stanowiły nie tylko definicje i ich formalna znajomość, lecz również poczucie wyrażających się nie w słowach, lecz w czynach uczuć oraz woli. „Jasne myślenie”, rozumiane jako splot pierwiastków rozumowego i uczuciowego, jest dla Sokratesa, miarodajne dla działania i posiada siłę aktywizującą, podczas gdy słowne definicje są na ogół niewystarczające i zbyt słabe, by rządzić czynami ${ }^{31}$. Uruchomienie siły aktywizującej wydaje się kluczowe dla wszelkiej zmiany.

$\mathrm{Na}$ uświadomione mówienie składa się poprawność formalna (aspekt intelektualny) oraz „zgoda” na to, co się drogą intelektualną przyjęło (aspekt emocjonalny). Można podać formalnie poprawną definicję i wcale nie być do niej przekonanym. „Co innego zaś jest uzasadnić jakieś twierdzenie, a co innego wiedzieć, że się je uzasadniło. Co innego jest zrobić coś dobrze, a co innego wiedzieć, że się to dobrze zrobiło"32. Obok dwóch wspomnianych aspektów, intelektualnego i emocjonalnego, pozostaje, nieuwzględniony wcześniej, czynnik trzeci, bodaj najistotniejszy, zapośredniczająca proces uobecnienia siebie - uwaga. Zachęcając do mówienia w sposób uświadomiony, czuwał Sokrates nad tym, by uwaga uczniów obejmowała dwie wspomniane strony. Dzięki takiemu ćwiczeniu uczniowie odnosili się do podejmowanych zagadnień z dużą samoświadomością. Powiedzieć można, że podczas dyskusji przeżywali oni uważnie ich własne procesy psychiczne ${ }^{33}$. Odnosząc się do jakiegoś zjawiska, czy zagadnienia, uświadamiali je sobie poprzez myślenie i doświadczanie. Dwa są bowiem sposoby uświadamiania sobie jakiegoś zjawiska: jeden „polega na tym, że się o tym zjawisku myśli, że się je spostrzega,

31 Tamże, 8.

32 K. Ajdukiewicz, Propedeutyka filozofii dla liceów ogólnokształcących, Lwów - Warszawa 1938, 35.

33 Tamże, 160. 
wspomina”, drugi - „na tym, że się je przeżywa”34. W ten sposób oba porządki, rozumu i serca, w równym stopniu były uwzględniane $\mathrm{w}$ procesach poznawczych, $\mathrm{w}$ tym również w rozpoznawaniu własnej postawy moralnej. Myliłby się jednak ten, kto wspomniane procesy sprowadziłby tylko do uważności. W naszym przekonaniu uwaga jedynie zapośrednicza głębiej zachodzące procesy, związane $\mathrm{z}$ uobecnieniem siebie poprzez aktywny odbiór doznań towarzyszących całemu procesowi.

Pozostaje zapytać, w jaki sposób uruchomić i pokierować procesem uobecniania siebie. Wyrażając się w języku intuicji homeryckich, powiedzieć możemy, że siła uczuciowego zapału (thymos) ma władzę nad ciałem. Ciało jest też jej siedliskiem. Chcąc obserwować przejawy cielesno-czynnej siły serca należałoby objąć uwagą ciało wykonujące czyn i towarzyszące mu doznania.

$\mathrm{W}$ proponowanej przez nas interpretacji uświadomione mówienie wymaga obejmowania uwagą procesów myślowych i uczuciowych. W równym stopniu uwagę należy kierować na treść wypowiedzi oraz na towarzyszące jej odczucia i doznania.

$\mathrm{Z}$ punktu widzenia psychologii homeryckiej powiedzieć możemy, że metoda maieutyczna Sokratesa, rozumiana jako uświadomione mówienie, wymagała uobecnienia siebie $\mathrm{w}$ ciele. $\mathrm{W}$ przeciwieństwie do stanu biernego (obecności tylko dusz-cielesnych ker i fren) myślenie i odczuwanie w sposób czynny wymagało obecności pierwiastka duchowego - przywołania dusz-niecielesnych (thymos i nous).

Jaśniejsze stają się zatem słowa Sokratesa porównującego własną metodę do położnictwa i odbierania płodów. Skoro „myśleć” oznaczało „rozmawiać $\mathrm{z}$ własną duszą”, a warunkiem tej rozmowy było uobecnienie duszy w ciele, to możliwe, że przez „płody” należy rozumieć stan, w którym rozmówca wchodził w kontakt z własnymi duszami nie-cielesnymi. Efektem ubocznym tego kontaktu było zdobycie pojęciowej wiedzy, istotą - obcowanie $\mathrm{z}$ sobą samym, swoim

34 Tamże, 159. 
„duchowym rdzeniem”. Dzięki metodzie majeutycznej docierał Sokrates wraz z rozmówcą, do wiedzy zgodnej z jego prawdziwym i najgłębszym $J a$ - zawartej w jego nie-cielesnych duszach.

Poza argumentami praktycznymi, do których się jeszcze odwołamy na poparcie postawionej tezy, dotyczącej sokratejskiej maieutyki, nie mamy wielu zapisów pochodzących z przekazu antycznego. Jako ilustrację do postawionej tezy wybrałem fragment Ptaków Arystofanesa, autora nieprzychylnego Sokratesowi i nie raz się z niego naśmiewającego. Bywa jednak, że zjadliwa krytyka tym bardziej jest celna, im więcej zawiera odwołań do faktycznych zdarzeń!

„W Cienionogów ziemi ludnej

Jest bajoro, kędy brudny

Wróż (psychagogei) Sokrates wabi dusze...

I Peisandros tam w otusze

Biegnie ujrzeć ducha (psyche) swego,

Co za życia umknął z niego...

Więc w ofierze nad tym brodem

Zażga wielbłądziątko młode

I jak Odys czeka zjawy...

Naraz do kałuży krwawej

Wionie $\mathrm{z}$ bagna maniacka

Larwa Chajrefonta-gacka" ${ }^{35}$.

35 Arystofanes, Ptaki, tłum. z gr. J. Jedlicz, Warszawa 1954, 156 (1532-1543).

Inne tłumaczenia:

„W Stopocieńców, hen krainie

jest jezioro; duchy tam

wywołuje brudny dziad,

Sokrat-mędrek (psychagogei)... W strony owe

przyszedł Peisandr: duszę (psyche) własną,

co mu czmychła, ujrzeć chciał...

Na ofiarę taszczył drab

wielbłądziego rodu jagnię.

Niby Odys ciął po gardle,

siadł - i czekał ... Aż obaczył - 
W cytowanym fragmencie Ptaków, Sokrates porównany jest do Odyseusza, przywołującego duszę zmarłego Terezjasza poprzez złożenie ofiary z krwi zwierzęcia. Sokrates ma pomóc składającemu ofiarę Peisandrosowi w odzyskaniu duszy, która mu umknęła. Nie wdając się w dyskusję, czy Sokratesa postrzegać można nie tylko jako psychagoga, ale i psychopompa, przyjmujemy, że określenie psychagogia nie jest przypadkowe. W platońskim Fedonie znajdujemy wzmiankę o psychagogii w kontekście dyskusji o retoryce, która definiowana jest jako prowadzenie duszy ${ }^{36}$. To określenie pada również w przytoczonym przez nas fragmencie Ptaków Arystofanesa. Gdyby było to tylko przypadkowe sformułowanie, to Platon po około czterdziestu latach

Chajrefonta - nietoperza,

co na krew spod ziemi lazł".

Arystofanes, Ptaki, w: Arystofanes, Wybór komedii: Osy, Pokój, Ptaki, Tesmoforie, tłum z gr. S. Srebrny, Warszawa 1955, 347 (1580-1666).

„W sławnem państwie Cienionogich

jest jezioro, kędy Sokrat,

mędrzec (psychagogei) brudny, dusze (psyche) wabi.

Tam Pejsandros, ... arystokrat,

przyszedł szukać duszy, którą

żywcem zgubił gdzieś, niebożę!

Przywiódł z sobą wielbłądziątko, -

temu zaraz krtań przeorze,

i uskoczy w bok, jak Odyss;

aż tu nagle z Hadu łon,

krwią wielbłądzią przywabiony

leci gacek... Chajrefon".

Arystofanes, Ptaki, tłum. z gr. B. Butrymowicz, Kraków 1922, 134-135 (1554-1564).

36 „Nieprawdaż, że sztuka wymowy w ogóle jest sztuką prowadzenia dusz ludzkich (psychagogia) za pomocą mów, i to nie tylko w sądach i jakie tam inne zebrania, czy zgromadzenia publiczne, ale i w prywatnych kłótniach". Platon, Faidros, w: Dialogi, tłum. z gr. W. Witwicki, Kęty 1999, 2, 160, (161-161 B). „Skoro w naturze mowy leży zdolność do prowadzenia dusz (psychagogia), to człowiek, który chce być mówcą musi koniecznie wiedzieć, ile form dusza posiada". Tamże, 175 (171 C-171 D). 
od premiery Ptaków Arystofanesa nie wkładałby w usta Sokratesa terminu psychagogia, wyśmianego przez greckiego komediopisarza ${ }^{37}$.

\section{5. ĆWICZENIA DUCHOWE - RELACJE OSÓB ĆWICZĄCYCH}

Opierając się na zgromadzonym materiale teoretycznym i jego interpretacji, wprowadzono ćwiczenie uświadomionego mówienia do zajęć akademickich, zatytułowanych: Jak praktycznie wykorzystać wtasnq gtupote - doradztwo filozoficzne w warsztacie psychologa. Przygotowując ćwiczenie przyjęto, że przeżywając akt spostrzegania, możemy zwrócić uwagę na sam ten akt - możemy niejako myśl swą skierować na nasze własne spostrzeganie. „Możemy to uczynić w odniesieniu do każdego niemal procesu, który się rozgrywa w naszej psychice"38. Zwykle jednak tego nie czynimy, ponieważ po zautomatyzowaniu jakiejś czynności złożonej, nie jest do jej wykonania potrzebne świadome zdanie sobie sprawy z tworzących ją czynności składowych ${ }^{39}$. $\mathrm{Na}$ ogół osoba wypowiadająca się w sposób nawykowy nie umie podać komponentów wchodzących w skład jej aktu mowy. Dopiero włączenie uwagi i objęcie nią strony intelektualnej i emocjonalnej może uczynić automatyczne wypowiadanie się uświadomionym. Możliwym do spostrzeżenia staje się wtedy odpowiedź na pytanie, czy aktami naszymi kieruje nawyk, przyzwyczajenie (pamięć mięśniowa - u Homera obszar: etor, phren), emocja, a więc siła uczuciowego zapału (thymos), czy rozumny umysł (noos).

W latach 2004-2012 zbierane były od osób ćwiczących opisy doznań towarzyszących ćwiczeniu uświadomionego mówienia w formie krótkiego opisu. $Z$ wywiadami tymi czytelnik może zapoznać się

37 Ch. Moore, Socrates Psychagôgos (Birds 1555, Phaedrus 261a7), w: Socratica III: International Socrates Studies, Studies on Socrates, the Socratics, and the Ancient Socratic Literature, red. F. de Luise, A. Stavru, Sankt Augustin 2013, 42. (http://sites.psu.edu/ moore/wp-content/uploads/sites/13881/2014/09/Moore-Psychagogia.pdf)

38 K. Ajdukiewicz, dz. cyt. 9.

39 Tamże, 182-183. 
$\mathrm{w}$ innych pracach ${ }^{40}$. Kilka ćwiczeń zostało nagranych za pomocą kamery ${ }^{41}$. Obecnie chcemy przedstawić materiał zebrany podczas warsztatów: Anamneza jako droga odnajdywania wtasnej esencji, przeprowadzonych w ramach konferencji w Opolu w dniu 28 listopada 2016. Podczas jednodniowych zajęć kulminacyjnym momentem było ćwiczenie uświadomionego mówienia. W ćwiczeniu wzięło udział kilka osób, które zgłosiły się na ochotnika. Osoby te zostały poproszone o opisanie własnego stanu psychofizycznego podczas ćwiczenia i bezpośrednio po nim. Przytaczamy opisy osób, które pozytywnie odpowiedziały na zaproszenie do udziału w badaniu. Poniżej relacje tych osób.

„Biorąc udział w ćwiczeniu (...), przekonałyśmy się, że »uświadomione mówienie« nie należy do łatwych praktyk. Polega ono na wypowiedzeniu kilku zdań oraz zlokalizowaniu własnej uwagi. Szybko można zauważyć, że w zależności od tego, na czym skupiona jest uwaga, ton głosu ulega zmianie: jeśli uwaga jest zorientowana do wewnątrz, wówczas wypowiedź jest »pełna esencji«, bardziej szczera, przepełniona emocjami. Ćwiczenie »uświadomionego mówienia« pozwala uwrażliwić jednostkę na dostrzeżenie w sobie prawdy oraz na spontaniczne za prawdą tą podążanie. Wiele z tego, co robimy na co dzień, jest przez nas wykonywane w sposób mechaniczny, bez głębszego namysłu, bez sięgnięcia do naszego świata wewnętrznego. Ćwiczenia, w których wzięłyśmy udział, miały na celu - mówiąc po

40 T. Femiak, Narodziny głosu - sztuka uświadomionego mówienia, jako narzędzie rozpoznawania głosu, w: Psychologia narracyjna. Tożsamość, dialogowość, red. E. Dryll, A Cierpka, Eneteia, Warszawa 2011, s. 43-62. T. Femiak, O sztuce uświadomionego mówienia - czyli jakiej filozofii uczniowie potrzebują (rzecz o wychowawczych i rozwojowych aspektach filozofii), Edukacja Filozoficzna 32(2001), 147-160.

41 Z jednym z filmów można się zapoznać na stronie internetowej: https://www.youtube. com/watch?v=8_e20nUDtkw [dostęp: 23.05.2018] lub http://faroegoeimi.wix.com/ egoeimi [dostęp: 23.05.2018]. 
platońsku - "wyzwolenie się z kajdan« oraz wyjście z tak zwanego Zombielandu (...)"42.

„Nauczona doświadczeniem z poprzednich warsztatów, obserwowałam swój głos. Mówiłam o czymkolwiek. Prowadzący poprosił o unaocznienie uwagi. Wyobraziłam ją sobie jako mglistą kulę. Kazał mi ją wchłonąć, czyli skupić uwagę na wysokości brzucha. Tak się stało. Polecił mi, bym opowiadała o sobie. Nie pamiętam, co mówiłam, ale głos był inny - myślałam bardziej nad tym, co mówiłam, i starałam się czuć w sobie tę mglistą kulę. To trwało jakiś czas, co kilka chwil prosił mnie, bym bardziej utrzymała uwagę wewnątrz siebie. Potem zapytał mnie jak widzę świat i tu zaczął się problem. Ja nie widziałam świata ani przed wchłonięciem tej mglistej kuli, ani po. Było mi trudno wyjaśnić, że u mnie nie ma różnicy. Wreszcie po kilku pytaniach zobaczyłam, jak gdyby, bo przed oczami nie ma ciemności, jest gęsta, nieprzenikniona przestrzeń, bardziej bym ją porównała do szarości. Na tle tej szarości uwidoczniła mi się, trudno powiedzieć, że ją zobaczyłam, ale uwidoczniła mi się postać prowadzącego, ale dwuwymiarowo. Tak jakby wycięta z papieru. Było to mocniejsze niż zwykle. Przez sekundę widziałam biało-niebieskie światło. Przypominało mi to przeżycie chwili »jasności«, kiedy w rozpaczy po śmierci mamy doznałam czegoś, co interpretowałam jako sygnał od mamy: »jest mi tu dobrze, nie martw się«. Ja już nie pamiętam, o czym rozmawialiśmy, co mówiłam. Ale wiem, że byłam wewnętrznie bardzo poruszona. Bardzo poruszona. Nie wiem może... można to porównać do drżenia, do... poczucia swojego wnętrza... $\mathrm{O}$, byłam rozedrgana. Tak bym to określiła. Kiedy usiadłam, byłam jeszcze w tym stanie. Taka jakby nie w tej przestrzeni” 43 .

42 P. Jarząb, M. Głodek, Konferencja Wokół idei doradztwa filozoficznego, w: Uniwersytet Zielonogórski - Miesięcznik Społeczności Akademickiej, Zielona Góra 2015, 9-11 (229-230), 57. (http://www.uz.zgora.pl/wydawnictwo/miesiecznik12-2015/miesiecznik12-2015.pdf).

43 A. zaczęła chorować w wieku 8 lat, ostatecznie straciła wzrok w wieku 15 lat. Swoje postrzeganie rozmówców w codziennych konwersacjach określa jako dwuwymiarowe. Na podstawie wywiadu przeprowadzonego przez dr. Piotra Leśniaka. 
„Obawiam się, że pełne zobiektywizowanie, jakiego wymaga dyskurs naukowy, tego wszystkiego, co się wydarzyło podczas ćwiczenia byłoby spłaszczeniem. Odczytuję to w płaszczyźnie religijnej, (...)

1) Uwolnienie emocji

Szloch na zajęciach podczas ćwiczenia uświadomionego mówienia był takim oczyszczeniem $z$ wewnętrznego ściśnięcia po śmierci matki. Bardzo długotrwałego. Kiedy wracałam do domu po warsztatach, poczułam bardzo realny "przypływ miłości do bliskich«. Wcześniej czułam się zniewolona sytuacją. Myślałam realnie o ucieczce... Teraz wydało mi się to śmieszne. Pierwszą rzeczą, jaką oznajmiłam mężowi, było to, że kocham go całym sercem. Potem poczułam potrzebę powiedzenia o tym dzieciom. (...) takie realne odczucie miłości ma niesamowite przełożenie na odczucia erotyczne. Seks staje się radosny i czuły. Niezwykle integrujący.

2) Wzrost uważności

Zwiększyła się u mnie zdolność słuchania. Uczucia, które pojawiły się we mnie, nie miały charakteru zaburzającego percepcję. (...)

3) Wzrost wrażliwości

Skłonność do przeżyć empatycznych. Wyraźniej widać emocje innych. Dostrzega się ludzi jako istoty czujące.

4) Otwartość na doznania religijne

$\mathrm{Na}$ drugi dzień po warsztatach wstałam wcześniej i zaczęłam się modlić. W czasie modlitwy moje ciało przeszedł bardzo przyjemny dreszcz, rozwarłam ręce, w dłoniach poczułam prąd, który od środka przenikał całe ciało. Czułam, że jeśli przeciwstawię się temu, wszystko się skończy, ale chciałam, by to trwało. Oddech mój przyspieszał. Odczuwałam ten prąd jako coś oczyszczającego i obezwładniającego, ale jednoznacznie pozytywnego. Nie miałam żadnych wątpliwości, że jest to dobre (...).

Kiedy wstałam po kilku (?) minutach, poczułam, co to znaczy być natchnioną przez Ducha. Czułam, że nie do końca panuję nad sobą, jednak cały czas zachowywałam poczucie, że mogę wrócić do »normalności«, jeśli tylko zechcę. W tym stanie, takiego radosnego 
uniesienia, nagle ujrzałam siebie w kontekście zdarzeń w przeszłości zobaczyłam obrazy, które niejako oddawały sens tego, co wydarzało się w moim życiu (...)"44.

Mimo że w chwili obecnej dysponujemy jedynie surowymi zapisami relacji osób ćwiczących uświadomione mówienie, to zgromadzone wywiady inspirują do badań głębszych, wymagających jeszcze wielu analiz. Aż nadto znajdujemy w nim podobieństw i powtarzających się elementów. Zmiana tembru głosu, mimiki i wyrazu twarzy, poczucia wglądu i uniesienia emocjonalnego. Jeżeli uda się zebrać zespół badawczy i odpowiednie środki, to fenomen uświadomionego mówienia zostanie zbadany za pomocą wystandaryzowanych metod badawczych.

\section{ZARYS DALSZYCH BADAŃ}

Przedstawiony materiał pozwala na postawienie kilku hipotez. Uświadomione mówienie - forma uobecnienia siebie - jako część sokratejskiej maieutyki było nie tylko formą dialogu, a przede wszystkim praktyczną metodą głębokiej pracy duchowej, zakorzenionej w starożytnych wierzeniach i antycznej psychologii. Potwierdzają to niektóre teksty, a teraz w wymowny sposób praktyka filozoficzna. Zaproponowana przez nas interpretacja metody sokratejskiej zbieżna jest z podejściem zaproponowanym przez K. Poppera i P. Hadota. Pierwszy opisywał dialektykę jako sztukę ,intelektualnego przewidywania, wyobrażania sobie boskich oryginałów, form czyli idei, odkrywania »Wielkiej Tajemnicy«, ukrytej poza zwykłym światem zjawisk"45. Drugi - ćwiczenie czystej myśli, z poddaniem się

44 Ze względu na prośbę o zachowanie anonimowości osoby badanej niektóre treści zostały zmienione.

45 K. Popper, Społeczeństwo otwarte i jego wrogowie, z ang. tłum. T. Korczyc, Warszawa 1987, 97. 
nakazom Logosu, odwodzeniem duszy od zmysłowego świata i zwróceniem się ku Dobru ${ }^{46}$.

Zdaje się, że dzięki praktyce uobecnienia siebie poprzez ucieleśnienie własnych części duszy sięgali antyczni Grecy do wiedzy-nadświadomości człowieka - daleko ważniejszej od normalnej codziennej ludzkiej świadomości. Wierzyli oni, że codzienna świadomość i niecodzienna nadświadomość mogą być udziałem tego samego człowieka ${ }^{47}$.

Choć zgromadzony materiał teoretyczny i empiryczny wymaga głębszego opracowania i jest jedynie zapowiedzią kontynuacji dalszych poszukiwań, możemy określić wstępne ramy dalszych badań procesów zachodzących u osób praktykujących uświadomione mówienie (ćwiczących uobecnienie siebie).

W ramach tych badań, chcielibyśmy opracować:

1. statystyczne ujęcie obserwowanych zmian: tembru głosu, mimiki i wyrazu twarzy, ruchu gałek ocznych;

2. badanie poziomu percepcji ciała, kontaktu z sobą, stanu równowagi i szczęścia;

3. zapis przeżyć towarzyszących ćwiczeniom;

4. zmiany w postawie życiowej.

Jeżeli badania potwierdzą prawidłowości, które zaobserwowaliśmy $\mathrm{w}$ fazie pilotażowej, to na tej podstawie będziemy mogli przyjąć, że uświadomione mówienie jako forma uobecnienia siebie może być traktowane jako forma terapii filozoficznej sensu stricto.

\section{ZAKOŃCZENIE}

Liczymy, że tekst niniejszy zachęci niektórych do rzetelnej krytyki i merytorycznego wsparcia badań, którego w wielu miejscach jeszcze potrzeba.

46 P. Hadot, Filozofia jako ćwiczenie duchowe, dz. cyt., 41.

47 D. Dembińska-Siury, Adama Krokiewicza teoria nadświadomości, dz. cyt., 21. 
Jeżeli nie uda się utrzymać naszej intuicyjnej interpretacji syntetycznej, zgodnie z którą, w rozmowie, Sokrates psychagog jednoczył i scalał poprzez zachęcenie do uświadomionego mówienia porządek serca i porządek rozumu, wywołując stan eutymii, to pozostaje jeszcze do wyjaśnienia sam fenomen zjawiska uświadomionego mówienia. Mylne przekonanie może przecież doprowadzić do odkrycia zjawisk nowych. $Z$ całą pewnością ćwiczenie uświadomionego mówienia zasługuje na zbadanie, gdyż daje wymierne skutki w dydaktyce akademickiej, pracy z młodzieżą licealną i z osobami dorosłymi, o czym starałem się już nie raz wskazywać $\mathrm{w}$ materiale pisemnym i za pomocą form zajęć warsztatowych.

\section{BIBLIOGRAFIA}

Ajdukiewicz K., Propedeutyka filozofii dla liceów ogólnoksztatcacych, Książnica Atlas, Lwów - Warszawa 1938.

Arystofanes, Ptaki, tłum. z gr. B. Butrymowicz, Krakowska Spółka Wydawnicza, Kraków 1922.

Arystofanes, Ptaki, tłum. z gr, J. Jedlicz, PIW, Warszawa 1954.

Arystofanes, Ptaki, w: Arystofanes, Wybór komedii: Osy, Pokój, Ptaki, Tesmoforie, tłum z gr. S. Srebrny, PIW, Warszawa 1955.

Dembińska-Siury D., Adama Krokiewicza teoria nadświadomości, Przegląd Humanistyczny (1987)31, 21-34.

Domański J., Metamorfozy pojęcia filozofii, Polska Akademia Nauk Instytut Filozofii i Socjologii, Warszawa 1996.

Femiak T., O sztuce uświadomionego mówienia - czyli jakiej filozofii uczniowie potrzebuja (rzecz o wychowawczych i rozwojowych aspektach fllozofii), Edukacja Filozoficzna 32(2001), 147-160.

Femiak T., Narodziny gtosu - sztuka uświadomionego mówienia, jako narzędzie rozpoznawania głosu, w: Psychologia narracyjna. Tożsamość, dialogowość, red. E. Dryll, A Cierpka, Enetheia, Warszawa 2011, 43-62.

Hadot P., Filozofia jako ćwiczenie duchowe, tłum. z fr. P. Domański, Aletheia, Warszawa 2003.

Hadot P., Czym jest filozofia starożytna, tłum. z fr. P. Domański, Aletheia, Warszawa 2003.

Homer, Odyseja, tłum. z gr. J. Parandowski, Czytelnik, Warszawa 1964. 
Homer, Odyseja, tłum z gr. L. Siemieński, Zielona Sowa, Kraków 2003.

Homer, Iliada, tłum z gr. L. Siemieński, Zielona Sowa, Kraków 2004.

Jarząb P., Głodek M., Konferencja "Wokót idei doradztwa filozoficznego”, w: Uniwersytet Zielonogórski - Miesięcznik Spoteczności Akademickiej, Zielona Góra 2015, 9-1 (229-230), 56-57. (http://www.uz.zgora.pl/wydawnictwo/miesiecznik12-2015/miesiecznik12-2015.pdf).

Kobierzycki T., Miejsce i rola uczuć w opisie duszy cielesnej i niecielesnej u Homera, Heksis (2010) 4, 3-15.

Krokiewicz A., Zarys fllozofii greckiej, Aletheia, Warszawa 2000.

Krokiewicz A., Sokrates. Etyka Demokryta i hedonizm Arystypa, Aletheia, Warszawa 2000.

Krokiewicz A. Studia orfickie. Moralność Homera i etyka Hezjoda, Aletheia, Warszawa 2000.

Moore Ch., Socrates Psychagôgos (Birds 1555, Phaedrus 261a7), w: Socratica III: International Socrates Studies, Studies on Socrates, the Socratics, and the Ancient Socratic Literature, red. F. de Luise, A. Stavru, Sankt Augustin 2013, 41-55. (http://sites.psu.edu/moore/wp-content/uploads/sites/13881/2014/09/Moore-Psychagogia.pdf).

Morenz S., Bóg i człowiek w starożytnym Egipcie, tłum. z niem. M. Szczudłowski, PIW, Warszawa 1972.

Leartios D., Żywoty i poglady stynnych filozofów, tłum. z gr. K. Leśniak, I. Krońska, W. Olszewski, Warszawa 1988.

Platon, Fedon, w: Dialogi, 1, tłum z gr. W. Witwicki, Kęty 1999, 627-714.

Platon, Teajtet, w: Dialogi, 2, tłum z gr. W. Witwicki, Kęty 1999, 327-431.

Platon, Faidros, w: Dialogi, 2, tłum z gr. W. Witwicki, Kęty 1999, 107-186.

Popper K., Spoteczeństwo otwarte i jego wrogowie, tłum. z ang. T. Korczyc, Niezależna Oficyna Wydawnicza, Warszawa 1987.

Stuligrosz M., Gnoma w twórczości Pindara, UAM, Poznań 2002.

Zieliński T., Psychologia homerycka, tłum. z ros. T. Kobierzycki, Heksis (1922/1999) $1-2,3-33$.

\section{ON MAKING THE SOUL PRESENT: SOCRATES PSYCHAGÔGOS AND THE ART OF CONSCIOUS SPEAKING}

Abstract. This article presents an intuitive and synthetic interpretation of Socratic maieutics. In it we share the results of the workshop series: 'How to make use of your own stupidity? Philosophical consulting in psychology', held at Warsaw University and the University of Social Sciences and Humanities in Warsaw from 2004 to 2012. This was the 
first seminar series on philosophical counseling examined in academic settings in Poland. Interpreting Socratic maieutics in the spirit of Homeric psychology contributed to the formulation of a number of exercises on conscious speaking, which were incorporated into academic teaching. Students were asked to write down their observations during an exercise, and some sessions were filmed. This allowed us to gather very interesting material, which was the basis for further theoretical and empirical research. In this article, I briefly illustrate conscious speaking, present notes from student exercises and share short recorded material.

Keywords: Homeric psychology, incorporeal souls: thymos and nous, corporeal souls: (soul-heart - kradié and diaphragm-soul - fren), Socratic method, art of conscious speaking, making oneself-present, spiritual exercises

\author{
TOMASZ FEMIAK \\ tfemiak@gmail.com \\ Uniwerystet Opolski, Wydział Nauk Społecznych, Instytut Filozofii \\ ul. Katowicka 89, 45-061 Opole
}

DOI: 10.21697/spch.2018.54.3.14 